\title{
Proteinuria is still useful for the screening and diagnosis of overt diabetic nephropathy ${ }^{1}$
}

\author{
Themis Zelmanovitz ${ }^{2}$, Jorge L. Gross ${ }^{2}$, Jarbas Oliveira², \\ Mirela J. de Azevedo
}

\begin{abstract}
OBJECTIVE: To assess the performance of urinary total protein measurements in timed 24-h urine collection and in a diurnal random urine specimen for the screening and diagnosis of overt diabetic nephropathy.

PATIENTS AND METHODS: A total of 167 diabetic patients (20 type 1 and 147 type 2 diabetic patients; 78 women and 89 men), aged 20-84 years, collected 217 timed 24-h urine specimens. Albumin was measured by immunoturbidimetry, total protein by the sulfosalicylic acid technique, and creatinine by Jaffés method. According to the timed 24-h urinary albumin excretion rate, samples were divided into three groups: normoalbuminuric (urinary albumin excretion rate $<20 \mu \mathrm{g} / \mathrm{min} ; n=84$ ), microalbuminuric (urinary albumin excretion rate $20-200 \mu \mathrm{g} / \mathrm{min} ; n=78$ ), and macroalbuminuric (urinary albumin excretion rate $>200 \mu \mathrm{g} / \mathrm{min} ; n=55$ ). Eight-six patients also collected 105 random urine specimens (normoalbuminuric, $n=47$; microalbuminuric, $n=37$; macroalbuminuric, $n=21$ ), and urinary protein concentration and urinary protein-to-creatinine ratio were measured. The receiver operating characteristics curve approach was used to analyze the performance of the diagnostic tests.
\end{abstract}

RESULTS: Spearman's coefficient of correlation of 24-h urinary albumin excretion rate versus $24-h$ urinary protein was $0.95(\mathrm{P}<0.001)$, and of 24-h urinary albumin excretion rate versus urinary protein concentration and urinary protein-to-creatinine ratio were 0.77 and 0.72 , respectively $P<0.001)$. The calculated areas $( \pm S E M)$ under the receiver operating characteristics curve for the diagnosis of overt diabetic nephropathy were $0.9987 \pm 0.001$ for 24-h urinary protein, $0.9926 \pm 0.006$ for urinary protein concentration, and $0.9751 \pm 0.014$ for urinary protein-to-creatinine ratio. In the receiver operating characteristics curves, the first points with $100 \%$ sensivity were $541 \mathrm{mg}$ (95.7\% specificity) for 24-h urinary protein, $431 \mathrm{mg} / \mathrm{l}$ (92.9\% specificity) for urinary protein concentration, and 0.2 (76.2\% specificity) for urinary protein-tocreatinine ratio.

CONCLUSIONS: Measurements of proteinuria presented almost perfect accuracy for the screening and diagnosis of overt diabetic nephropathy. Protein measurement in spot urine is a reliable and simple method for the screening and diagnosis of overt diabetic nephropathy.

Key-words: Urinary total protein measurements; random urine specimen; overt diabetic nephropathy.

\section{Proteinúria ainda é útil para triagem e diagnóstico de nefropatia diabética} sintomática

OBJETIVO: Avaliar a utilização de medições de proteína urinária total em coletas urinárias de 24 horas e em amostras diurnas coletadas aleatoriamente para triagem e diagnóstico de nefropatia diabética sintomática.

\footnotetext{
Este artigo foi publicado originalmente em Diabetes Care 1998;21:1076-9. Parte deste estudo foi apresentada no International Diabetes Federation Meeting, Helsinque, Finlândia, 21-24 de julho de 1997.

2 Departamento de Endocrinologia, Hospital de Clínicas de Porto Alegre, Porto Alegre, RS, Brasil.

Correspondência: Dr. Jorge Luiz Gross, Rua Ramiro Barcellos 2350, sala 2030, CEP 90035-003, Porto Alegre, RS, Brasil.Email: gross@hotnet.net
} 
PACIENTES E MÉTODOS: Foram coletadas 217 amostras de urina a cada $24 \mathrm{~h}$ de um total de 167 pacientes diabéticos (20 pacientes com diabetes tipo 1 e $147 \mathrm{com}$ diabetes tipo 2; 78 mulheres e 89 homens), com idade entre 20 e 84 anos. A albumina foi medida por imunoturbidimetria, a proteína urinário total foi medida pela técnica do ácido sulfosalicílico e a creatinina, pelo método de Jaffe. As amostras foram divididas em três grupos de acordo com a taxa de $24 \mathrm{~h}$ de excreção urinária de albumina: normoalbuminúricos (taxa de excreção urinária de albumina $<20 \mu \mathrm{g} / \mathrm{min}$; $n=84$ ), microalbuminúricos (taxa de excreção urinária de albumina 20-200 $\mu \mathrm{g} / \mathrm{min}$; $n=78$ ), e macroalbuminúricos (taxa de excreção urinária de albumina > $200 \mu \mathrm{g} / \mathrm{min}$; $n=55)$. Foram coletadas ainda 105 amostras aleatórias de urina de 86 pacientes (normoalbuminúricos, $n=47$; microalbuminúricos, $n=37$; macroalbuminúricos, $n=21$ ), das quais a concentração urinária de proteina e a relação proteína/creatinina urinária foram obtidas. O método da curva de características operacionais do receptor foi utilizado para analisar o desempenho dos testes diagnósticos.

RESULTADOS: O coeficiente de correlação de Spearman para a comparação entre a taxa de 24 h de excreção urinária de albumina e a proteina urinária de 24 h foi 0,95 $(\mathrm{P}<0,001)$. O mesmo coeficiente, para a comparação da taxa de 24 h de excreção urinária de albumina com a concentração urinária de proteina, assim como com a relação proteína/creatinina urinária foi 0,77 e 0,72, respectivamente $(P<0,001)$. As áreas calculadas ( \pm erro padrão) abaixo da curva de características operacionais do receptor para o diagnóstico de nefropatia diabética sintomática foram: 0,9987 $\pm 0,001$ para a proteina urinária de $24 h ; 0,9926 \pm 0,006$ para concentração urinária de proteína; e 0,9751 \pm 0,014 para a relação proteina/creatinina urinária. Nas curvas de características operacionais do receptor os primeiros pontos com $100 \%$ de sensitividade foram: $541 \mathrm{mg}$ (95,7\% de especificidade) para proteína urinária de 24 h, 431 mg/l (92,9\% de especificidade) para concentração urinária, e 0,2 (76,2\% de especificidade) para a relação proteína/creatinina urinária.

CONCLUSÕES: As medidas de proteinuria foram extremamente eficazes na triagem e no diagnóstico de nefropatia diabética sintomática. A medição de proteína urinária é um método confiável e simples para a triagem e diagnóstico de nefropatia diabética sintomática.

Unitermos: Medição de proteína urinária total; coleta aleatória de urina ; nefropatia diabética sintomática.

\section{Introduction}

The screening and diagnosis of diabetic nephropathy have been based on the measurement of urinary albumin excretion rate (UAER) in a timed 24-h or overnight urine collection; on albumin-to-creatinine ratio; or on albumin concentration in a random or earlymorning urine sample (1-5). The measurement of urinary albumin by accurate methods (immunoturbidimetry or radioimmunoassay) is essential for the diagnosis of the microalbuminuric phase of diabetic nephropathy, or incipient nephropathy, which can be halted or even reversed if appropriate measures are taken (6). It was demonstrated that screening and intervention for microalbuminuria are worthwhile, can have life-saving effects, and lead to considerable economic savings (7). However, financial constraint in some diabetes clinics has been considered the main reason limiting the use of urinary albumin measurements to screen for diabetic nephropathy (8). Classically, the diagnosis of overt diabetic nephropathy is 
established when Albustix results are persistently positive or when total urinary protein (UP) excretion is $>0.5 \mathrm{~g} / 24 \mathrm{~h}(9)$. In a recently published position statement, the American Diabetes Association recommended that screening for diabetic nephropathy should start with a routine urinalysis for protein (10). A dipstick test iis used by most laboratories and is considered to have high sensitivity. A positive test result ought to be confirmed by quantitative protein measurement. IIf the test result is negative, measurement of albuminuria is necessary. The measurement of proteinuria by biochemical methods is simple and inexpensive and could increase the accuracy of the dipstick test for the initial screening of diabetic nephropathy. There are few data comparing the dipstick test with measurements of total proteinuria and albuminuria for the diagnosis of overt diabetic nephropathy $(11,12)$.

The aim of this study was to asses the performance of total UP measurements in timed 24-h urine collection and in a diurnal randon urine sample (RUS) for the screening and diagnosis of overt diabetic nephropathy by using the receiver operating characteristics (ROC) curve approach.

\section{Patients and methods}

We performed a study of diagnostic tests
for overt diabetic nephropathy (macroalbuminuria). The criterion standard was timed 24-h UAER. The study was done at the outpatient diabetes clinic at Hospital de Clínicas de Porto Alegre (HCPA) (a tertiary care center). Informed consent was obtained from each patient, and the protocol was approved by the ethics commitee.

Every type 1 and type 2 diabetic patient (defined according to the World Health Organization's criteria) without evidence of cardiac failure or renal tract disease other than nephropathy (urinary tract infection, hematuria, abnormal urinary sediment, plasma creatinine increase without proteinuria) was considered for the study.

The study population consisted of 167 ambulatory diabetic patients (20 type 1 and 147 type 2 diabetic patients; 78 women and 89 men), aged $56.9 \pm 12.3$ years (range 20-84). Patients were instructed in the collection of timed 24-h urine for measurement of UAER and total protein and were told to return on the morning after the end of urine collection. No specific recommendation was made about fluid intake, physical exercise, or dietary protein intake. Women were not examined during menstruation. The patients collected 217 timed 24-h urine specimens, all confirmed to be sterile by culture. According to 24-h UAER (criterion standard), samples were divided into three groups: normoalbuminuric (NORMO) (UAER < $20 \mu \mathrm{g} / \mathrm{min}$; $\mathrm{n}=84$ ), microalbuminuric (MICRO) (UAER 20$20020 \mu \mathrm{g} / \mathrm{min} ; \mathrm{n}=78)$, and macroalbuminuric (MACRO) (UAER $\geq 200 \mu \mathrm{g} / \mathrm{min} ; \mathrm{n}=55)$. During the morning visit to the clinic, after completing the timed 24-h urine collection and after the first voided urine sample (not necessarily the second voided urine sample), 86 patients also collected RUSs for measurements of urinary protein concentration (UPC) and urinary protein-tocreatinine ratio (UPCR), as well as for the dipstick test. Fasting was not a criterion for collecting the RUS sample. This procedure was performed twice by 19 patients on different occasions; then 105 urine samples were analyzed. According to the 24-h UAERs, these samples were also divided into NORMO $(n=47)$, MICRO $(n=37)$, and MACRO $(n=21)$ groups.

Urinary albumin was measured by immunoturbidimetry (Sera-Pak, Bayer, Tarrytown NY) in duplicate. The mean intra and interassay coefficients of variation (CVs) are 4.5 and $11.0 \%$, respectively, at our laboratory. Urinary total protein was measured by the quantitative 3\% sulfosalicylic acid technique (13). The mean intraassay $\mathrm{CV}$ was $4.8 \%$, and it was calculated from the 24-h samples using three total UPCs: 124, 357, and $893 \mathrm{mg} / \mathrm{l}$. The individual intra-assay CVs of these samples were 1.6, 4.6, and $8.1 \%$, respectively. The semiquantitative dipstick method for proteinuria (Combur M, Boehringer Mannheim, Mannheim Germany) was performed according to the directions of the manufacturer. Urinary creatinine was measured by Jaffe's reaction $(\mathrm{CV}=7.2 \%)$ (CentrifiChem AutoAnalyser, Hoffman-La Roche, Basel, Switzerland).

The relationship between 24-h UAER and 24-h UP and RUS measurements (UPC and UPCR) was calculated by Spearman's correlation coefficient (rS). The contribution (\%) of urinary albumin to total protein in timed 24-h urine was 

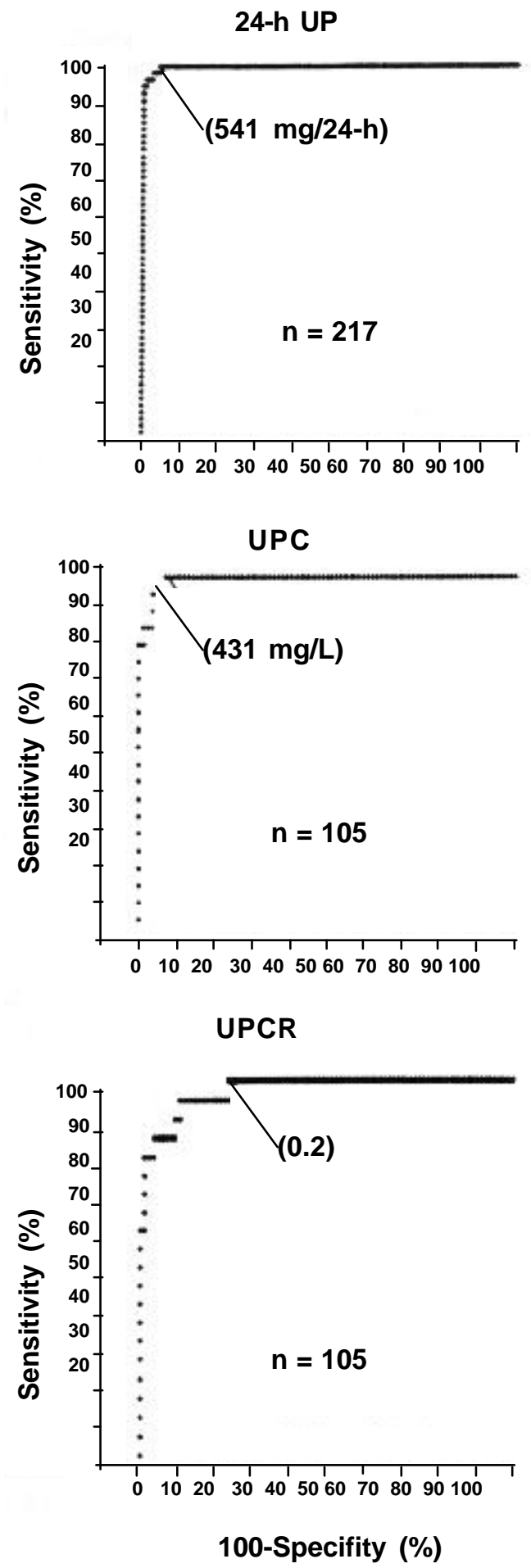

Figure 1. Receiver operating characteristics curves for total urinary protein, urinary protein concentration, and urinary protein-to-creatinine ratio as diagnostic tests for macroalbuminuria. Values in parenthesis correspond to the first point with $100 \%$ sensitivity.

determined in NORMO, MICRO and MACRO samples, and the contributions of urinary albumin to total protein were compared using the KruskalWallis analysis of variance (ANOVA) and nonparametric multiple comparison test. Sensitivities and specificities of total protein measurements in timed 24-h urine and in RUSs (UPCs and UPCRs) as a diagnostic test for overt diabetic nephropathy were calculated in each sample. The ROC-curve approach was used to analyze the performance of the screening tests. The true-positive rate (sensitivity) versus the false-positive rate (100 - specificity) was plotted for each measurement. The first point with 100\% sensitivity was chosen in each curve, and a second cutoff point was also determined in each curve by the intersection of the curves with the $100 \%$-to- $100 \%$ diagonal. The latter point represents the best equilibrium between sensitivity and specificity. The statistical analises of ROC curves were done using a Visicalc program (14) and the ROC Analyser software version 5.0, wich calculates the area under the curves (15). In assessing the accuracy of the Combur $\mathrm{M}$ test for the diagnosis of overt diabetic nephropathy, the 24-h UAER was considered the criterion standard. The level of significance was set at 0.05 .

\section{Results}

The correlation of 24-h UAER to 24-h UP was $0.95(n=217 ; P<0.001)$. When these urine samples were divided into the NORMO, MICRO and MACRO groups, the values for $\mathrm{rS}$ were 0.61 , 0.80 , and 0.95 , respectively $(P<0.001)$. The rS values of 24-h UAER versus UPC and UPCR were 0.77 and 0.72 , respectively $(P<0.001)$.

The median values and range of 24-h UAER and 24-h UP of 217 samples classified as NORMO, MICRO and MACRO, and the contribution of albumin to total protein in each sample group are shown in Table 1. The mean contribution of urinary albumin to total protein is lower in NORMO samples than in MICRO and MACRO samples. No difference was observed between MICRO and MACRO samples $(P<0.05$, Kruskal-Wallis ANOVA).

Figure 1 depicts the ROC curves for 24-h UP $(n=217)$ and UPC and UPCR $(n=105)$ as diagnostic tests for overt diabetic nephropathy. The calculated area ( $($ SEM) under the ROC curves for the 24-h UP was $0.9987 \pm 0.001$. The calculated areas under the ROC curves for RUS measurements for UPC $(0.9926 \pm 0.006)$ and UPCR $(0.9751 \pm 0.014)$ did not differ. 
Table 1. Measurements of 24-h urinary albumin excretion rate, 24-h urinary protein, and contribution of albumin to total protein in the 217 urine samples $^{a}$

\begin{tabular}{|c|c|c|c|c|}
\hline Sample group & $\mathrm{n}$ & $\begin{array}{l}\text { 24-h urinary albumin } \\
\text { excretion rate }(\mu \mathrm{g} / \mathrm{min})\end{array}$ & $\begin{array}{l}\text { 24-h urinary protein } \\
\text { (mg/24-h) }\end{array}$ & $\begin{array}{l}\text { Contribution of albumin to total } \\
\text { protein }(\%)\end{array}$ \\
\hline NORMO & 84 & $4.9(0.1-19.5)$ & $45.7 \quad(6.5-323.7)$ & $16.8 \quad(0.42-47.5)$ \\
\hline MICRO & 78 & $69.6 \quad(20.3-197.8)$ & $230.9(51.6-625.1)$ & $44.2(14.3-76.5)$ \\
\hline MACRO & 55 & $627.7 \quad(201.2-4,056.8)$ & $2,133.1 \quad(541.2-12,123.5)$ & $47.1 \quad(33.4-79.2)$ \\
\hline
\end{tabular}

aData are expressed as median range, except for contributions of albumin to total protein, wich are expressed as mean range.

Table 2 presents the characteristics of the cutoff points for diagnosis of overt diabetic nephropathy according to the first point with a sensitivity of $100 \%$ and the nearest point to the intersection of the curves with the 100\%-to-100\% diagonal. At these two cutoff points, the corresponding values of 24-h UAER were 201.2 and $312.1 \mu \mathrm{g} / \mathrm{min}$, respectively, for 24-h UP. For the chosen UPC cutoff points, the corresponding 24-h UAER values were $307.1 \mu \mathrm{g} / \mathrm{min}$ (first point with a sensitivity of $100 \%$ ) and $185.3 \mu \mathrm{g} / \mathrm{min}$ (intersection of $100 \%$-to- $100 \%$ diagonal). For the UPCR cutoff points these values were 307.1 and $672 \mu \mathrm{g} / \mathrm{min}$, respectively.

When the performance of 24-h UP as a diagnostic test for microalbuminuria was analyzed, the calculated area under the ROC curve ( \pm SEM) was $0.9665 \pm 0.0106$. In this curve, the first point with $100 \%$ sensitivity for the diagnosis of microalbuminuria was $51.6 \mathrm{mg} / 24-$ h (53.6\% specificity) and the point determined by the intersection of the curve with the $100 \%$ to- $100 \%$ diagonal was $134 \mathrm{mg} / 24-\mathrm{h}(90.9 \%$ sensitivity; $90.5 \%$ specificity).
The Combur M test presented a $100 \%$ sensitivity for the diagnosis of overt diabetic nephropathy, according to the 24-h UAER. Falsepositive results were observed in about $18 \%$ of speciments (82.8\% specificity). The accuracy of the Combur $\mathrm{M}$ test was $86.7 \%$.

\section{Conclusions}

The data presented in this study showed that quantitative measurements of total UP in both 24-h and spot urine samples, as analyzed by the area under the ROC curve, are accurate for the screening and diagnosis of overt diabetic nephropathy. The values of the estimated area under the curves were close to 1.0, which represents perfect accuracy. Interestingly, the $100 \%$-sensitivity cutoff value of $541 \mathrm{mg}$ in $24-\mathrm{h}$ urine is very similar to the value of $500 \mathrm{mg} / 24-\mathrm{h}$, which was adopted to define overt diabetic nephropathy (9). Few studies have compared the measurements of total proteinuria and albuminuria for the diagnosis of diabetic nephropathy $(11,12)$. These studies analyzed

Table 2. Characteristics of the cutoff points of 24-hour urinary protein, urinary protein concentration, and urinary protein-to-creatinine ratio as diagnostic tests for overt diabetic nephropathya

\begin{tabular}{|c|c|c|c|c|c|c|}
\hline & \multicolumn{2}{|c|}{$\begin{array}{c}\text { 24-h urinary protein } \\
(\mathrm{mg} / 24 \mathrm{~h})\end{array}$} & \multicolumn{2}{|c|}{$\begin{array}{c}\text { Urinary protein } \\
\text { concentration (mg/l) }\end{array}$} & \multicolumn{2}{|c|}{$\begin{array}{l}\text { Urinary protein-to- } \\
\text { creatinine ratio }(\mathrm{mg} / \mathrm{mg})\end{array}$} \\
\hline & Cutoff1 & Cutoff2 & Cutoff1 & Cutoff2 & Cutoff1 & Cutoff2 \\
\hline Cutoff point & 541 & 568 & 431 & 490 & 0.2 & 0.5 \\
\hline Sensitivity (\%) & 100 & 98.2 & 100 & 95.2 & 100 & 90.5 \\
\hline Specificity (\%) & 95.7 & 97.5 & 92.9 & 95.2 & 76.2 & 90.5 \\
\hline Accuracy (\%) & 96.8 & 97.7 & 94.3 & 95.2 & 80.9 & 90.5 \\
\hline
\end{tabular}

${ }^{a}$ Cutoff 1 is the first cutoff point with $100 \%$ sensitivity; cutoff 2 is the nearest point to the intersection of the curve with the $100 \%$-to- $100 \%$ diagonal. 
only patients with overt diabetic nephropathy (11) or were designed for the diagnosis of microalbuminuria (12) and did not use the ROCcurve approach. The ROC curve has been used to evaluate overall test performance $(14,15)$ and to compare the discriminating ability of clinical tests (16). As far as we know, no other study used this approach to analyze the performance of proteinuria for the diagnosis of overt diabetic nephropathy. For the screening of a disease , it is desirable to have a test that is highly sensitive and, if possible, highly specific (17). High sensitivity and specificity were found in the present study because the $100 \%$-sensitivity cutoff values of total proteinuria in 24-h and random urine (UPC) were highly specific (95.7 and $92.9 \%$, respectively). This was not observed when proteinuria was corrected for urine creatinine in spot urine (UPCR). The specificity was only $76.2 \%$ at the cutoff value with $100 \%$ sensitivity. This means that about $25 \%$ of patients diagnosed by this test as having overt diabetic nephropathy would go on to be wrongly diagnosed. These errors are probably due to an increase in tubular secretion of creatinine in patients with nephrotic syndrome (18) and the interference of ketone bodies and some drugs in the creatinine assay method (19).

Moreover, the creatinine measurement increases the cost of the screening test. The quantitative measurement of total protein in the same spot sample of urine that is positive on the semiquantitative dipstick test will increase the accuracy of routine urinalysis for the diagnosis of overt diabetic nephropathy. Furthermore, the measurement of total protein in an RUS could be used to follow patients with overt diabetic nephropathy at a lower cost than the measurement of albuminuria. At our institution, the cost per test iis as follows (all amounts expreessed in U.S. currency): dipstick method, $\$ 0.61$; protein measurement by sulfosalicylic method, \$0.71; automated immunoturbidimetry for albumin, \$0.78. These economic data took into account the cost of the materials used (Combur M, \$0.51 per strip; sulfosalicylic method, $\$ 0.001$; automated immunoturbidimetry for albumin, \$0.77), the time spent to perform each test $(1.00,1.68,0.10 \mathrm{~min}$, respectively), and the hourly rate of a technician $(\$ 6.00)$.

This study confirms that 24-h proteinuria is not suitable for the screening of microalbuminuria because the specificity of the first point with $100 \%$ sensitivity on the ROC curve was unacceptably low. Considering that the detection of microalbuminuria iis important in forestalling the development of advanced renal disease (5), it is imperative that accurate methods be used to test dipstick negative urine samples for albuminuria.

The use of 24-h UP and UAER produced a positive and significant correlation over a wide range of values. This correlation was stronger in macroalbuminuric (0.95) and microalbuminuric (0.80) samples than in normoalbuminuric samples (0.61). A close correlation between albumin and total protein excretion was also observed by other authors in a small sample ( $n$ $=11$ ) of type 1 diabetic patients with overt dibetic nephropathy (11). The weaker correlation in normoalbuminuric samples could be explained by a diminutive fraction of albumin in the total protein at those low levels of proteinuria. After the development of diabetic renal disease, there is a progressive increase in urinary albumin and total protein excretion. The mean contribution of albumin to total protein was approximately $45 \%$ in both micro- and macroalbuminuric samples, wich was significantly different from the proportion found in the normoalbuminuric samples (17\%). These results are similar to those previously reported by Viberti et al. (20), who observed that the contribution of albumin to total protein was respectively 7,15 , and $42 \%$ in the urine samples of control subjects (UAER range 4.3-26.2 mg/24 h), patients with microproteinuria (UAER $<150$ $\mathrm{mg} / 24 \mathrm{~h}$; range, 18.7-122.8) and patients with macroproteinuria (UAER > $150 \mathrm{mg} / 24 \mathrm{~h}$; range 157-6257). The different proportions observed in the microproteinuric group and our microalbuminuric group are probably due to the different criteria used to classify the patients. According to the current classification of stages of diabetic nephropathy (10), patients with UAER levels in the upper range of microalbuminuria were excluded, and normoalbuminuric patients were included, in the group classified as microproteinuric by Viberti et al. (20).

In conclusion, proteinuria demonstrated almost perfect accuracy for the screening and diagnosis of overt diabetic nephropathy. Protein measurement in spot urine is a reliable and simple method for the screening and diagnosis of overt diabetic nephropathy. 
Acknowledgements. This study was suported by grants from Fundação de Amparo à pesquisa do Rio Grande do Sul (FAPERGS), Fundo de Incentivo à Pesquisa, Hospital de Clínicas de Porto Alegre, and Programa de Apoio a Núcleos de Excelência. T.Z. is the recipient of a scholarship from Coordenação de Aperfeiçoamento de Pessoal de Ensino Superior (CAPES).

\section{References}

1. International Diabetes Federation, St. Vincent's Declaration, World Health Organization. Consensus Guidelines for the Management of InsulinDependent (Type I) Diabetes. European IDDM Police Group, Eds. Bussum, The Netherlands, Medicom Europe, 1993.

2. Bennet PH, Haffner S, Kasiske BL, Keane WF, Mogensen $\mathrm{CE}$, Parving $\mathrm{HH}$, et al. Screening and management of microalbuminuria in patients with diabetes mellitus: recommendations to the Scientific Advisory Board of the National Kidney Foundation from Ad Hoc Commitee of the Council on Diabetes Mellitus of the National Kidney Foundation. Am J Kidney Dis 1995;25:107-12.

3. Mogensen CE, Vestbo E, Poulsen PL, Christiansen $C$, Damsgaard EM, Eiskjaer $\mathrm{H}$, et al. Microalbuminuria and the potential confounders: a review and some observations on variability of urinary albumin excretion. Diabetes Care 1995;18:572-81.

4. Warram JH, Gearin G, Laffel L, Krolewski AS. Effect of type 1 diabetes on the prevalence of stages of diabetic nephropathy defined by urinary albumin creatinine ratio. J Am Soc Nephrol 1996;7:1-8.

5. Zelmanovitz T, Gross JL, Oliveira JR, Paggi A, Tatsch M, Azevedo MJ: The receiver operating characteristics curve in the evaluation of a random urine specimen as a screening test for dibetic nephropathy. Diabetes Care 1997;20:516-9.

6. Mogensen CE, Keane WF, Bennet PH, Jerums G, Parving $\mathrm{H}-\mathrm{H}$, Passa $\mathrm{P}$, Steffes MW, Striker GE, Viberti GC. Prevention of diabetic renal disease with special reference to microalbuminuria. Lancet 1995;346:1080-4.
7. Borch-Johnsen K, Wenzel H, Viberti GC, Mogensen $C E$. Is screening and intervention for microalbuminuria worthwhile in patients with insulin dependent diabetes? BMJ 1993;306:1722-5.

8. Gazis A, Page SR: Microalbuminuria screening in the UK: are we meeting European standards? Diabet Med 1996;13:764-7.

9. Ireland JT, Viberti GC, Watkins PJ. The kidney and urinary tract. In: Keen H, Jarret J, eds. Complications of Diabetes. 2nd ed. London: Edward Arnold; 1982. p. 137-78.

10. American Diabetes Association: Diabetic nephropathy (position Statement). Diabetes Care 1998;21 (Suppl. 1):S50-3.

11. Sasse EA, Doumas BT, Lemann Jr. J. Diabetic nephropathy: urinary albumin or total protein? Ann Intern Med 1989;111:343-4.

12. Phillipou G, James SK, Seaborn CJ, Phillips PJ. Screening for microalbuminuria by use of rapid, lowcost colorimetric assay. Clin Chem 1989;35:456-8.

13. Bradley M, Schuman GB, Ward PCJ. Examination of urine. In: Henry JB, ed. Clinical Diagnosis and Management by Laboratory Methods. 16th ed. Philadelphia: WB Saunders; 1979. p. 559-634.

14. Centor RM. A Visicalc program for estimating the area under a receiver operating characteristic $(\mathrm{ROC})$ curve. Med Decis Making 1985;5:139-48.

15. Hanley JA, McNeil BJ. The meaning and use of the area under a receiver operating characteristic $(\mathrm{ROC})$ curve. Radiology 1982;143:29-36.

16. Hanley JA, McNell BJ. A method of comparing the areas under a receiver operating characteristics curves derived from the same cases. Radiology 1983;148:839-43.

17. Flechter RH, Flechter SW, Wagner EH. Diagnosis. In: Clinical Epidemiology: The Essentials. 3rd ed. Baltimore: Williams \& Willkins; 1996. p. 43-74.

18. Carrie BJ, Golbeltz HV, Michaels AS, Myers BD. Creatinine: an inadequate filtration marker in glomerular diseases. Am J Med 1980;69:177-82.

19. Payne RB. Cratinine clearance: a redundant clinical investigation. Ann Clin Biochem 1986;23:243-50.

20. Viberti GC, Mackintosh D, Keen H. Determinants of the penetration of proteins through the glomerular barrier in insulin-dependent diabetes mellitus. Diabetes 1983;32 (Suppl. 2):92-5. 